\title{
Equilibrium Study and Biological Activity of Cu(II) with Polyvinyl alcohol (PVA) and Some Amino acids and DNA.
}

\author{
Perihan. A. Khalaf -Alaa, Wafaa M. Hosny \\ Chemistry Department, Faculty of Science, Cairo University, Giza, Egypt \\ dr_wafaa1960@yahoo.co.uk
}

\begin{abstract}
This study presents the acid-base equilibrium of polyvinyl alcohol (PVA). The stability constant values of the binary and ternary complexes formed in solution among polyvinyl alcohol, $\mathrm{Cu}$ (II), some amino acids and DNA were determined potentiomertically. The stability constants of the complexes are determined and the concentration distribution diagrams of the complexes are evaluated. The ligand and their metal chelates have been screened for their antimicrobial activities using the disc diffusion method against the selected bacteria and fungi. Binary and ternary complexes of copper (II) involving polyvinyl alcohol (PVA) and various biologically relevant ligands containing different functional groups, were investigated. The ligands (L) are amino acids and DNA constituents. The ternary complexes of amino acids and DNA are formed by simultaneous and stepwise reactions respectively. The results showed the formation of $\mathrm{Cu}$ (PVA) (L) complexes with amino acids and DNA. Amino acids form both $\mathrm{Cu}$ (PVA)(L) complexes and the corresponding protonated $\mathrm{Cu}(\mathrm{PVA})(\mathrm{LH})$ and deprotonated species $\mathrm{Cu}(\mathrm{PVA})\left(\mathrm{LH}_{-1}\right)$. The ternary complexes of copper (II) with (PVA) and DNA are formed in a stepwise process, whereby binding of copper (II) to (PVA) is followed by ligation of the DNA components. DNA constituents form 1:1 complexes with $\mathrm{Cu}$ (PVA). The stability of these ternary complexes was quantitatively compared with their corresponding binary complexes in terms of the parameter $\Delta \log _{10} K$. The values of $\Delta \log _{10} K$ indicate that the ternary complexes containing aromatic amino acids were significantly more stable than the complexes containing alkyl- and hydroxyl alkyl substituted amino acids. The concentration distribution of various complex species formed in solution was also evaluated as a function of $\mathrm{pH}$. The antimicrobial activities using the disc diffusion method against some selected bacteria and fungi. The activity data show that the metal complexes are found to have antibacterial and antifungal activity.
\end{abstract}

\section{Keywords}

Copper(II). PVA. Amino acids. DNA constituents- Stability constant

\section{Academic Discipline and Sub-Disciplines}

Education

\section{Subject Classification}

QD146-197 Inorganic chemistry

\section{Type (METHOD/APPROACH)}

Quasi-Experimental

\section{Council for Innovative Research}

Peer Review Research Publishing System

Journal: Journal of Advances in Chemistry

Vol 3, No. 3

editor@cirworld.com

wWw.cirworld.com, member.cirworld.com 


\section{Introduction}

Poly (vinyl alcohol) (PVA; -[-CH-CHOH-]n-) is the world's largest volume synthetic polymer produced for its excellent chemical resistance and physical properties and complete biodegradability, which has led to broad practicable applications. PVA is a semicrystalline polymer whose crystalline index depends on the synthetic process and the physical aging [1,2]. PVA is a water-soluble polyhydroxy polymer, one few linear, non-halogenated aliphatic polymers. PVA has a two dimensional hydrogen-bonded network sheet structure. The physical and chemical properties of PVA depend to a great extent on its method of preparation. Poly(vinyl alcohol) could be considered as a good host material due to good thermo-stability, chemical resistance and film forming ability. PVA is an important material in view of its large scale applications. It is used in surgical devices, sutures, hybrid islet transplantation, implantation, blend membrane and in synthetic cartilage in reconstructive joint surgery [3-6]. In this investigation we report a quantitative study of the acid base equilibrium of PVA, as well as the binary complex formation equilibrium with $\mathrm{Cu}(\mathrm{II})$. $\mathrm{Mixed}$ ligand complexes involving $\mathrm{Cu}$-PVA and some amino acids and DNA constituents are studied and the concentration distributions of the complexes are evaluated.

\section{Experimental}

\subsection{Materials and Reagents}

PVA (average MWt : 27000, Aldrich makes). Glycine, alanine, threonine, methionine, proline, serine, $\beta$-phenylalanine, lysine, imidazole, L-histidine $\cdot \mathrm{HCl}$, and L-histamine $2 \mathrm{HCl}$, were provided by the Sigma Chem. Co. The DNA constituents' uracil, uridine, thymine, thymidine, inosine, inosine 5'-monophosphate and adenosine 5-monophosphate were supplied by BDH-Biochemicals Ltd. For stability constant determination, solutions of (PVA) were prepared in deionized water, freshly prepared solutions of (PVA) were used for all the measurements. L-histidine $\cdot \mathrm{HCl}$ was prepared in one equivalent of $\mathrm{HNO} 3$ acid, $\mathrm{Cu}(\mathrm{NO} 3) 2 \cdot 2 \mathrm{H} 2 \mathrm{O}$ was provided by $\mathrm{BDH}$. The copper content of the solutions was determined by complexometric EDTA titrations [7]. Carbonate free $\mathrm{NaOH}$ (titrant) was prepared and standardized against potassium hydrogen phthalate solution. All chemicals were of the highest purity commercially available and were used without further purification. All solutions were prepared in deionized water by dissolving the chemicals shortly before use.

\subsection{Biological Activity}

The metal complexes were evaluated for their antibacterial activity against Staphylococcus aureus (Gram-positive bacteria), Escherichia coli (Gram-negative bacteria) and also for their antifungal activity against Candida albicans and Aspergillus flavus using the disc diffusion technique as described in British Pharmacopoeia (2000). Nutrient agar was melted at $45.00{ }^{\circ} \mathrm{C}$, and inoculated with the cell suspension (1:100) bacteria or yeast. The flask was shaken well and poured into a Petri-dish (15 $\mathrm{cm}$ in diameter). Filter paper discs $(6 \mathrm{~mm})$ Whatman No. 2 were thoroughly moistened with antibiotics $(50 \mathrm{~g})$. The treated discs were aseptically transferred and placed on the surface of the inoculated plates and kept in a refrigerator for $1 \mathrm{~h}$ to permit diffusion of antimicrobial substances. The plates were incubated at $37.00{ }^{\circ} \mathrm{C}$ for $24 \mathrm{hr}$., and at $28.00{ }^{\circ} \mathrm{C}$ for $48 \mathrm{hr}$., in case of bacteria and fungi, respectively. The zones of inhibition were measured in $\mathrm{mm}$. The mean values of inhibition were calculated for triple readings in each test [8,9]. The antibacterial and antifungal activities are calculated as a mean of three replicates. The antibacterial and antifungal activity of a common standard antibiotic Ampicillin and Amphotericine B were also recorded using the same protocol and at the same concentration and solvent. The antibacterial and antifungal results of the complexes were compared with the standard and the \% activity index for the M(II) complexes were calculated by using the formula:

$$
\% \text { Activity index }=\frac{\text { Zone of inhibition by test complexes (diameter) }}{\text { Zone of inhibition by standard (diameter) }} \times 100
$$

\subsection{Apparatus and Measuring Techniques}

Potentiometric measurements were made using a Metrohm 751 Titrino. The titroprosessor and electrode were calibrated with standard buffer solutions, prepared according to NBS specifications[10] at $25 \pm 0.1^{\circ} \mathrm{C}$ and $\mathrm{I}=0.1 \mathrm{~mol} \mathrm{dm}{ }^{-3}$, potassium hydrogen phthalate (pH $4.008)$ and a mixture of $\mathrm{KH} 2 \mathrm{PO} 4$ and Na2HPO4 $(\mathrm{pH} 6.865)$. A $\left(0.10 \mathrm{~mol} \mathrm{dm}^{-3}\right)$ standard acid solution was titrated with a standard base $\left(0.10 \mathrm{~mol} \mathrm{dm}^{-3}\right)$ to convert the $\mathrm{pH}$ meter reading into hydrogen ion concentration. The $\mathrm{pH}$ values was plotted against $\mathrm{p}[\mathrm{H}]$, where the relation $\mathrm{pH}-\mathrm{p}[\mathrm{H}]=0.5$ was observed for all the titration data. A pKw value of $13.997[11]$ was used to calculate the [OH']. The titrations were performed in a thermostated titration vessel equipped with a magnetic stirring system, under purified N2 atmosphere using $0.05 \mathrm{M} \mathrm{NaOH}$ as titrant. The titrations were performed at a constant ionic strength of $0.1 \mathrm{~mol}^{-3} \mathrm{dm}^{-3}$ (NaNO3). The acid dissociation constants of the ligand were determined by titrating a $40 \mathrm{ml}$ of ligand solution $\left(1.25 \times 10^{-3} \mathrm{~mol} \mathrm{dm}^{-3}\right)$. The formation constants of the complexes were determined by titrating $40 \mathrm{~mL}$ of the solution containing metal ion $\left(1.25 \times 10^{-4} \mathrm{~mol} \mathrm{dm}^{-3}\right)$ and ligand $\left(1.25 \times 10^{-3} \mathrm{~mol} \mathrm{dm}^{-3}\right)$. The stability constant values were calculated by using the computer program MINIQUAD-75[12]. Various possible composition models were tried to calculate the stoichiometry and stability constants of the system studied. The model selected was that which gave the best statistical fit as described before [12]. The experimental titration data were compared with the theoretical curve calculated from the acid dissociation constant values of the ligand and the formation constants of their complexes, to check the validity of the selected model. Table 1 lists the stability constants together with their standard deviations and the sum of the squares of the residuals derived from the MINIQUAD output. The speciation diagrams were obtained using the program SPECIES [13]. UV-Vis spectrophotometric measurements were carried out using automated spectrophotometer UV-Vis Thermo Fischer Scientific Model Evolution 60 ranged from 200 to $900 \mathrm{~nm}$. 


\subsection{Equilibrium Measurements}

The acid dissociation constants of the ligands were determined potentiometrically by titrating the ligand $\left(40 \mathrm{~cm}^{3}\right)$ solution $\left(1.25 \times 10^{-3}\right.$ $\mathrm{mol} \cdot \mathrm{dm}^{-3}$ ) of constant ionic strength $0.1 \mathrm{~mol} \cdot \mathrm{dm}$ (adjusted with NaNO3). The stability constant of the $\mathrm{Cu}(\mathrm{PVA})$ complex was determined by titrating $40 \mathrm{~cm}^{3}$ of a solution mixture of $\mathrm{Cu}^{\text {II }}\left(1.25 \times 10^{-3} \mathrm{~mol} \cdot \mathrm{dm}^{-3}\right)$, PVA ligand $\left(2.5 \times 10^{-3} \mathrm{~mol} \cdot \mathrm{dm}^{-3}\right)$ and NaNO3 $(0.1$ $\mathrm{mol} \cdot \mathrm{dm}^{-3}$ ). The formation constant of the mixed ligand complexes were determined by titrating solution mixtures containing equivalent amounts of $\mathrm{Cu}^{\mathrm{II}}\left(1.25 \times 10^{-3} \mathrm{~cm}^{3}\right)$, PVA and other ligands in the concentration ratio 1:1:1 for amino acids and the DNA constituents.

All titrations were performed in a purified N2 atmosphere using aqueous $0.05 \mathrm{~mol} \cdot \mathrm{dm}^{-3} \mathrm{NaOH}$ as titrant. The general four component equilibrium can be written as follow in eqns.( 1 and 2$)$ (, (charges are omitted for simplicity)

$$
\begin{gathered}
\mathbf{l}(\mathbf{C u})+\mathbf{p}(\text { PVA })+q(L)+r(H) \leftrightarrow(C u) l(P V A) p(L) q(H) r \\
\beta l p q r=\frac{[(C u) l(P r o m) p(L) q(H) r]}{[C u]^{1}[\text { Prom }]^{\mathrm{p}}[L]^{\mathrm{q}}[\mathbf{H}]^{\mathrm{r}}}
\end{gathered}
$$

\subsection{Spectrophotometric Measurements}

Spectrophotometric investigation of the binary and ternary complexes was performed by scanning the visible spectra of solution mixtures 1-6. It is assumed that the complexes have been completely formed after neutralization of the hydrogen ions released under the experimental conditions. Mixtures 1-6 were prepared to be used for spectrophotometric measurements. In each case the volume is made up to $10 \mathrm{~cm}^{3}$ by water, and the ionic strength is kept constant by using NaNO3 $\left(0.1 \mathrm{~mol} \cdot \mathrm{dm}^{-3}\right)$

1. $1.0 \mathrm{~cm}^{3} \mathrm{Cu}$ (II) $\left(0.01 \mathrm{~mol} \cdot \mathrm{dm}^{-3}\right)+1.25 \mathrm{~cm}^{3} \mathrm{NaNO} 3\left(0.8 \mathrm{~mol} \cdot \mathrm{dm}^{-3}\right)$

2. $1.0 \mathrm{~cm}^{3}$ glycine or thymidine $\left(0.01 \mathrm{~mol} \cdot \mathrm{dm}^{-3}\right)+1.25 \mathrm{~cm}^{3} \mathrm{NaNO} 3\left(0.8 \mathrm{~mol} \cdot \mathrm{dm}^{-3}\right)$

3. $1.0 \mathrm{~cm}^{3}$ PVA $\left(0.01 \mathrm{~mol} \cdot \mathrm{dm}^{-3}\right)+1.25 \mathrm{~cm}^{3} \mathrm{NaNO} 3\left(0.8 \mathrm{~mol} \cdot \mathrm{dm}^{-3}\right)$

4. $1.0 \mathrm{~cm}^{3} \mathrm{Cu}(\mathrm{II})\left(0.01 \mathrm{~mol} \cdot \mathrm{dm}^{-3}\right)+1.0 \mathrm{~cm}^{3} \mathrm{PVA}\left(0.01 \mathrm{~mol} \cdot \mathrm{dm}^{-3}\right)+1.25 \mathrm{~cm}^{3} \mathrm{NaNO} 3\left(0.8 \mathrm{~mol} \cdot \mathrm{dm}^{-3}\right)$

5. $1.0 \mathrm{~cm}^{3} \mathrm{Cu}(\mathrm{II})\left(0.01 \mathrm{~mol} \cdot \mathrm{dm}^{-3}\right)+1.0 \mathrm{~cm}^{3}$ glycine or thymidine $\left(0.01 \mathrm{~mol} \cdot \mathrm{dm}^{-3}\right)+1.25 \mathrm{~cm}^{3} \mathrm{NaNO} 3\left(0.8 \mathrm{~mol} \cdot \mathrm{dm}^{-3}\right) 6.1 .0$

$\mathrm{cm}^{3} \mathrm{Cu}$ (II) $\left(0.01 \mathrm{~mol} \cdot \mathrm{dm}^{-3}\right)+1.0 \mathrm{~cm}^{3}$ PVA $\left(0.01 \mathrm{~mol} \cdot \mathrm{dm}^{-3}\right)+1.0 \mathrm{~cm}^{3}$ glycine or thymidine

$\left(0.01 \mathrm{~mol} \cdot \mathrm{dm}^{-3}\right)+1.25 \mathrm{~cm}^{3} \mathrm{NaNO} 3\left(0.8 \mathrm{~mol} \cdot \mathrm{dm}^{-3}\right)$

\section{Results and Discussion}

The acid dissociation constant of the PVA and the formation constants of their binary complexes presented in Table 1 , the potentiometric equilibrium titration curve of PVA, Fig. 1, shows the presence of one buffer region in which the hydroxyl group is neutralized $\left(\mathrm{pKa}=10.89\right.$ at $25^{\circ} \mathrm{C}$ ), yielding the anionic species $\mathrm{PVA}^{-1}$, which starts to form above $\mathrm{pH}=6$. The stability of the binary complex of $\mathrm{Cu}(\mathrm{II})$ and different amino acids were studied applying potentiometric measurements. The stability constants of binary complexes are plotted in Table 1 . The concentration distributions of $\mathrm{Cu}$-glycine and $\mathrm{Cu}$-Threonine as representative curves occur in Figs. 2 and 3. The curve of binary complexes is significantly lower than PVA titration curve, due to the formation of a complex through release of a proton from a hydroxyl group. The experimental studies were done under the same ionic strength and temperature used to study the $\mathrm{Cu}(\mathrm{II})-\mathrm{PVA}$ and the corresponding ternary complexes. The results obtained are in good agreement with the literature data [14-16]

\subsection{Ternary Complex Formation}

Ternary complex formation may proceed either through a stepwise or a simultaneous mechanism depending on the chelating potential of polyvinyl alcohol and other ligands. The formation constants of the 1:1 copper(II) complexes with PVA and those of amino acids and DNA, taken from the literature and cited in Tables 1 and are nearly of the same order. Consequently the ligation of PVA and amino acids will proceed stepwise. The validity of this model was verified, by comparing the potentiometric data with the theoretically calculated (simulated) presents such a comparison, taken as a representative one. Figs. 1 and 4 present the potentiometric titration curve for the $\mathrm{Cu}-\mathrm{PVA}$-glycine system and $\mathrm{Cu}-\mathrm{PVA}$ - thymidine system. Both curves resulted from the stepwise and simultaneous mechanism respectively.

\subsubsection{Complexes Involving Amino Acids}

The titration data of the ternary complexes with amino acids and PVA fit satisfactorily with formation of the species: $\mathrm{Cu}(\mathrm{PVA})^{+}$, $\mathrm{Cu}(\mathrm{PVA}) 2, \mathrm{Cu}(\mathrm{L}), \mathrm{Cu}(\mathrm{L}) 2, \mathrm{Cu}(\mathrm{PVA})(\mathrm{L}), \mathrm{Cu}(\mathrm{PVA})(\mathrm{L}-1)$ and $\mathrm{Cu}(\mathrm{PVA})(\mathrm{LH})$. The species distribution of glycine and ornithine, taken as representative amino acids, are given in Figs. 3 and 4. The protonated species 1111 in case of glycine complex attains a maximum

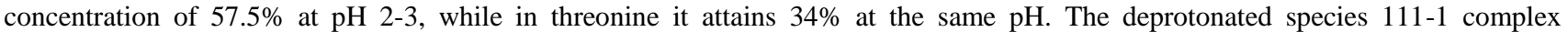
predominates, amounting to $99 \%$ in the physiological $\mathrm{pH}$ range 9-10, while the deprotonated species 1110 attains a maximum concentration of $71 \%$ at $\mathrm{pH} \approx 6.5$. Species with concentrations less than $5 \%$ were neglected in the concentration distribution plot for clarity. Threonine has an extra binding center on the $\beta$-alcohol-group. This group was reported to participate in complex formation [17]. The potentiometric data fit much better assuming the formation of the $\mathrm{Cu}(\mathrm{PVA})(\mathrm{LH}-1)$ species. This complex is formed through induced ionization of the $\beta$-alcohol group, as mentioned in the literature [17]. The $\mathrm{pKa}$ value of the $\beta$-alcoholato-group incorporated in the $\mathrm{Cu}(\mathrm{II})$ complex $\left(\log _{10} \beta_{1110-}\right.$ 
$\left.\log _{10} \beta_{111-1}\right)$ is 7.68. This is in good agreement with that reported in literature for the $\mathrm{Cu}$-threonine complex [18]. The $\log _{10} \beta_{1110}$ value is smaller than those for the amino acids. This may be attributed to the weaker coordination tendency of an alcohol group compared to a carboxylate group. Charge effects will also be important since the alcohol is neutral, whereas the carboxylate group is negatively charged. Due to the donation of the electron pair on oxygen to the metal center, the $\mathrm{OH}$ bond can be considerably weakened and the ionization of a proton occurs at a lower $\mathrm{pH}$. Histidine is a tridentate ligand having, amino, imidazole and carboxylate groups as binding sites. With $\mathrm{Cu}(\mathrm{PVA})$, only two of the three binding sites are involved in complex formation. Hence, histidine coordinates in either a glycine-like or histamine-like nitration of $\%$ at $\mathrm{pH}$ mode. The stability constant values of histidine and histamine are of the same order and considerably higher than those of amino acids, which indicate that both histidine and histamine will preferably coordinate through the amino and imidazole groups.
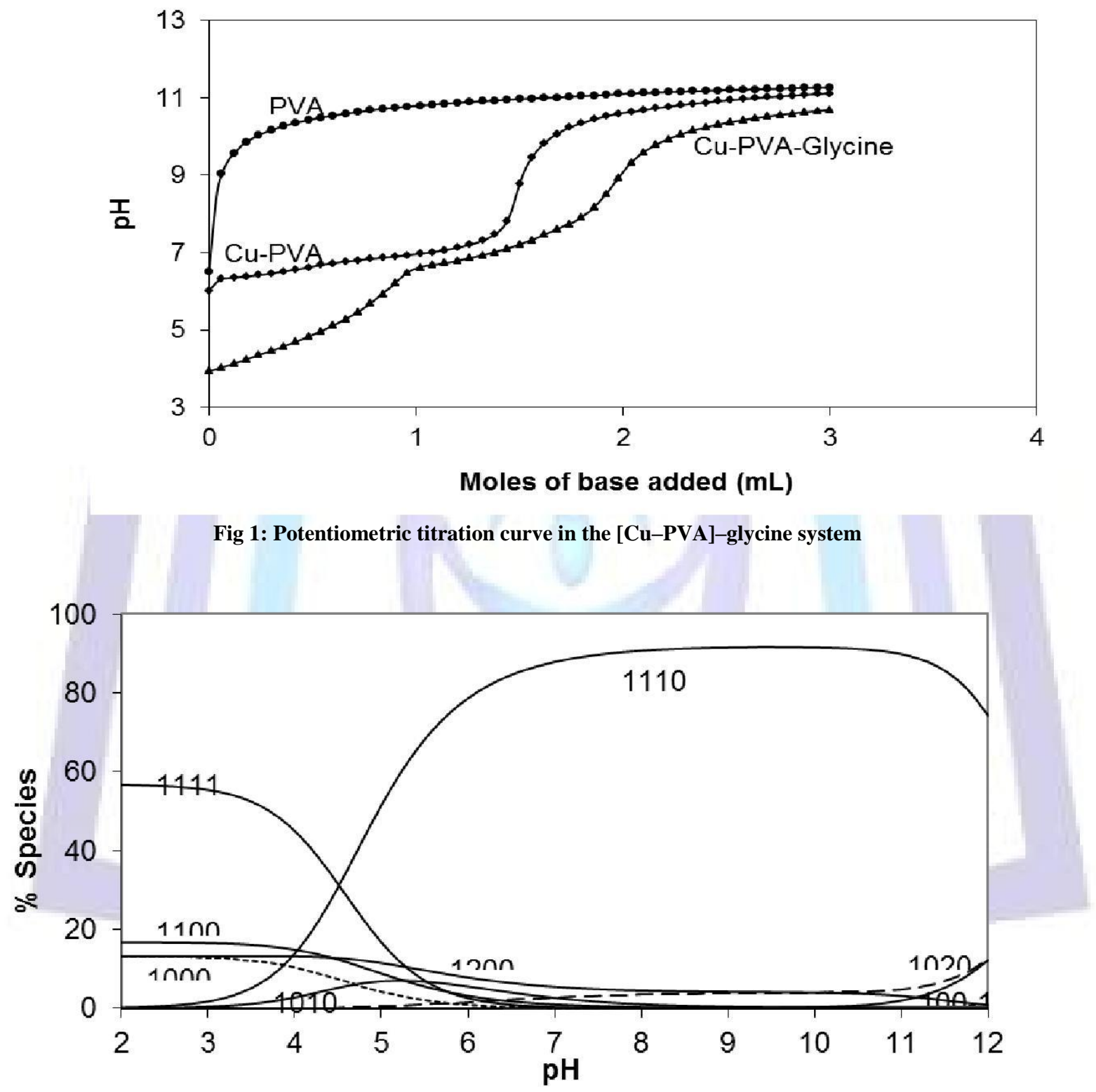

Fig 2: Concentration distribution of various species as a function of pH in the [Cu-PVA-glycine] system (each at a concentration of $1.25 \mathrm{mmol} \cdot \mathrm{L}^{-1}$ ) 


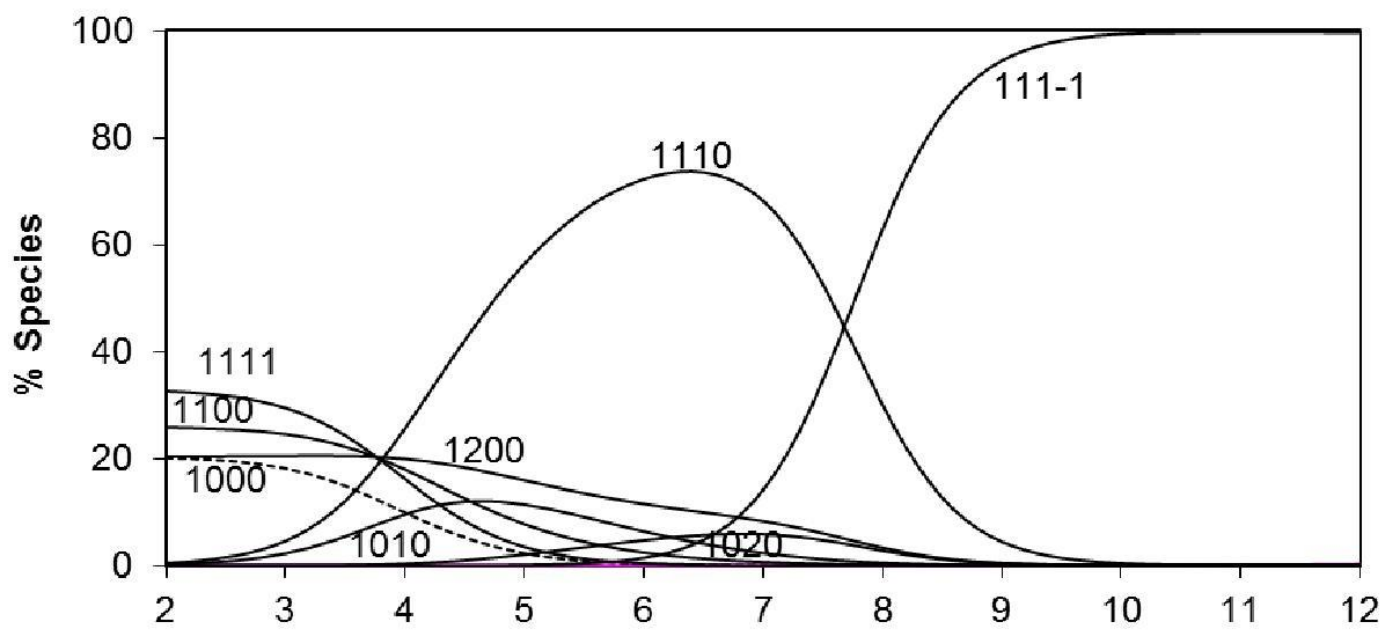

Fig 3: Concentration distribution of various species as a fungtipn of $\mathrm{pH}$ in the [Cu-PVA-threonine] system (each at a concentration of $1.25 \mathrm{mmol} \cdot \mathrm{L}^{-1}$ )

Table 1: Formation constants of the binary and ternary complexes in the $\mathrm{Cu}^{\mathrm{II}} \mathrm{PVA}$ amino acids at $25^{\circ} \mathrm{C}$ and $0.1 \mathrm{M}$ ionic strength

\begin{tabular}{|c|c|c|c|c|c|c|c|c|}
\hline System & I & $\mathbf{p}$ & $\mathbf{Q}$ & $\begin{array}{l}a \\
r\end{array}$ & $\log _{10} \beta^{b}$ & pKa & $S^{d} / 10^{-8}$ & $\Delta \log K$ \\
\hline \multirow[t]{2}{*}[\mathrm{Cu}(\mathrm{H}_{2}\mathrm{O})_{4}]{$^{2+}$} & 1 & 0 & 0 & -1 & $-6.44(0.07)$ & & 9.6 & \\
\hline & 1 & 0 & 0 & -2 & $12.99(0.02)$ & & & \\
\hline \multirow{4}{*}{ Cu-PVA } & 1 & 1 & 0 & 0 & $8.30(0.01)$ & & 1.7 & \\
\hline & 1 & 2 & 0 & 0 & $14.59(0.03)$ & & & \\
\hline & 1 & 1 & 0 & -1 & $0.95(0.02)$ & & & \\
\hline & 1 & 1 & 0 & -2 & $-10.39(0.05)$ & & & \\
\hline \multirow{8}{*}{ Glycine } & 0 & 0 & 1 & 1 & $9.60(0.01)$ & 9.60 & 1.6 & \\
\hline & 0 & 0 & 1 & 2 & $11.93(0.02)$ & 2.33 & & \\
\hline & 1 & 0 & 1 & 0 & $8.26(0.07)$ & & 3.0 & \\
\hline & 1 & 0 & 2 & 0 & $13.57(0.09)$ & & & \\
\hline & 1 & 0 & 1 & -1 & $0.34(0.08)$ & & & \\
\hline & 1 & 0 & 1 & -2 & $10.07(0.06)$ & & & \\
\hline & 1 & 1 & 1 & 0 & $16.61(0.01)$ & & 4.0 & 0.05 \\
\hline & 1 & 1 & 1 & 1 & $21.02(0.01)$ & 4.41 & & \\
\hline \multirow{8}{*}{ Alanine } & 0 & 0 & 1 & 1 & $9.69(0.01)$ & 9.69 & 9.3 & \\
\hline & 0 & 0 & 1 & 2 & $11.89(0.02)$ & 2.20 & & \\
\hline & 1 & 0 & 1 & 0 & $7.99(0.03)$ & & 3.1 & \\
\hline & 1 & 0 & 2 & 0 & $14.18(0.02)$ & & & \\
\hline & 1 & 0 & 1 & -1 & $-0.03(0.05)$ & & & \\
\hline & 1 & 0 & 1 & -2 & $-9.30(0.01)$ & & & \\
\hline & 1 & 1 & 1 & 0 & $16.28(0.02)$ & & 1.4 & -0.01 \\
\hline & 1 & 1 & 1 & 1 & $21.94(0.03)$ & 5.66 & & \\
\hline
\end{tabular}


ontC. Table 1.

\begin{tabular}{|c|c|c|c|c|c|c|c|c|}
\hline \multirow{8}{*}{$\begin{array}{c}\beta \text {-phenyl- } \\
\text { alanine }\end{array}$} & 0 & 0 & 1 & 1 & $9.12(0.01)$ & 9.12 & 2.0 & \\
\hline & 0 & 0 & 1 & 2 & $11.01(0.03)$ & 1.89 & & \\
\hline & 1 & 0 & 1 & 0 & $7.53(0.04)$ & & 4.3 & \\
\hline & 1 & 0 & 2 & 0 & $13.73(0.03)$ & & & \\
\hline & 1 & 0 & 1 & -1 & $0.01(0.05)$ & & & \\
\hline & 1 & 0 & 1 & -2 & $-10.08(0.03)$ & & & \\
\hline & 1 & 1 & 1 & 0 & $16.54(0.02)$ & & 1.6 & 0.71 \\
\hline & 1 & 1 & 1 & 1 & $20.62(0.03)$ & 4.08 & & \\
\hline \multirow{7}{*}{ Proline } & 0 & 0 & 1 & 1 & $10.52(0.01)$ & 10.52 & 5.6 & \\
\hline & 0 & 0 & 1 & 2 & $2.03(0.04)$ & 1.51 & & \\
\hline & 1 & 0 & 1 & 0 & $8.60(0.03)$ & & & \\
\hline & 1 & 0 & 2 & 0 & $15.09(0.01)$ & & & \\
\hline & 1 & 0 & 1 & -1 & $1.29(0.04)$ & & & \\
\hline & 1 & 1 & 1 & 0 & $16.90(0.03)$ & 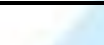 & & 0.00 \\
\hline & 1 & 1 & 1 & 1 & $21.25(0.02)$ & 4.35 & & \\
\hline \multirow{8}{*}{ Serine } & 0 & 0 & 1 & 1 & $9.14(0.02)$ & 9.14 & 5.3 & \\
\hline & 0 & 0 & 1 & 2 & $11.40(0.01)$ & 2.26 & & \\
\hline & 0 & 0 & 1 & -1 & $0.23(0.02)$ & & & \\
\hline & 1 & 0 & 1 & 0 & $8.40(0.02)$ & & & \\
\hline & 1 & 0 & 2 & 0 & $14.66(0.01)$ & & & \\
\hline & 1 & 1 & 1 & 0 & $16.15(0.02)$ & & 1.6 & -0.55 \\
\hline & 1 & 1 & 1 & 1 & $20.75(0.04)$ & 4.60 & & \\
\hline & 1 & 1 & 1 & -1 & $8.42(0.03)$ & 7.73 & & \\
\hline \multirow{6}{*}{ Lysine } & 0 & 0 & 1 & 1 & $10.44(0.02)$ & 10.44 & 2.8 & \\
\hline & 0 & 0 & 1 & 2 & $19.66(0.02)$ & 9.22 & & \\
\hline & 1 & 0 & 1 & 0 & $10.81(0.02)$ & & & \\
\hline & 1 & 0 & 2 & 0 & $18.22(0.02)$ & & & \\
\hline & 1 & 1 & 1 & 0 & $20.14(0.02)$ & & 1.4 & 1.03 \\
\hline & 1 & 1 & 1 & 1 & $26.39(0.02)$ & 6.25 & & \\
\hline \multirow{7}{*}{ Methionine } & 0 & 0 & 1 & 1 & $9.13(0.04)$ & 9.13 & 8.6 & \\
\hline & 0 & 0 & 1 & 2 & $1.10(0.02)$ & 1.97 & & \\
\hline & 1 & 0 & 1 & 0 & $8.02(0.04)$ & & & \\
\hline & 1 & 0 & 2 & 0 & $14.79(0.09)$ & & 1.5 & \\
\hline & 1 & 0 & 1 & -1 & $0.78(0.06)$ & & & \\
\hline & 1 & 1 & 1 & 0 & $15.35(0.03)$ & & 1.8 & -0.97 \\
\hline & 1 & 1 & 1 & 1 & $19.96(0.06)$ & 4.61 & & \\
\hline
\end{tabular}




\section{- Cont. Table 1}

\begin{tabular}{|c|c|c|c|c|c|c|c|c|}
\hline \multirow{6}{*}{ Imidazole } & 0 & 0 & 1 & 1 & $7.04(0.01)$ & 7.04 & 2.9 & est \\
\hline & 1 & 0 & 1 & 0 & $4.20(0.01)$ & & & \\
\hline & 1 & 0 & 2 & 0 & $7.62(0.04)$ & & 1.6 & \\
\hline & 1 & 0 & 3 & 0 & $10.35(0.05)$ & & & \\
\hline & 1 & 1 & 1 & 0 & $14.05(0.08)$ & & 1.2 & 1.55 \\
\hline & 1 & 1 & 1 & 1 & $21.28(0.03)$ & 7.23 & & \\
\hline \multirow{9}{*}{ Threonine } & 0 & 0 & 1 & 1 & $9.11(0.01)$ & 9.11 & 7.0 & \\
\hline & 0 & 0 & 1 & 2 & $11.32(0.02)$ & 2.21 & & \\
\hline & 1 & 0 & 1 & 0 & $7.97(0.03)$ & & 3.1 & \\
\hline & 1 & 0 & 2 & 0 & $14.13(0.04)$ & & & \\
\hline & 1 & 0 & 1 & -1 & $0.90(0.05)$ & 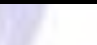 & & 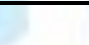 \\
\hline & $\frac{1}{1}$ & 0 & 1 & -2 & $\begin{array}{l}-8.93(0.02) \\
\end{array}$ & 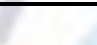 & . & \\
\hline & 1 & 1 & 1 & 0 & $16.43(0.02)$ & 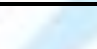 & 1.6 & 0.16 \\
\hline & 1 & 1 & 1 & 1 & $20.23(0.07)$ & 3.80 & & \\
\hline & $\frac{1}{1}$ & 1 & 1 & -1 & $8.75(0.06)$ & 7.68 & & -0.45 \\
\hline \multirow{9}{*}{ Histidine } & 0 & 0 & 1 & 1 & $9.53(0.01)$ & 9.53 & 1.8 & \\
\hline & 0 & 0 & 1 & 2 & $15.81(0.02)$ & 6.28 & & \\
\hline & 1 & 0 & 1 & 0 & $11.48(0.01)$ & & 1.6 & \\
\hline & 1 & 0 & 2 & 0 & $19.70(0.06)$ & & & \\
\hline & 1 & 0 & 1 & 1 & $15.75(0.04)$ & 4.27 & & \\
\hline & 1 & 0 & 1 & -1 & $6.82(0.03)$ & & & \\
\hline & 1 & 0 & 1 & -2 & $-3.77(0.04)$ & & & \\
\hline & 1 & 1 & 1 & 0 & $18.98(0.05)$ & & 8.6 & -0.80 \\
\hline & 1 & 1 & 1 & 1 & $23.64(0.05)$ & 4.66 & & -0.41 \\
\hline \multirow{9}{*}{ Histamine } & 0 & 0 & 1 & 1 & $9.88(0.01)$ & 9.88 & 1.4 & \\
\hline & 0 & 0 & 1 & 2 & $15.97(0.01)$ & 6.09 & & \\
\hline & 1 & 0 & 1 & 0 & $10.20(0.01)$ & & 1.6 & \\
\hline & 1 & 0 & 2 & 0 & $17.53(0.03)$ & & & \\
\hline & 1 & 0 & 1 & 1 & $14.89(0.01)$ & 4.69 & & \\
\hline & 1 & 0 & 1 & -1 & $3.48(0.04)$ & & & \\
\hline & 1 & 0 & 1 & -2 & $-5.86(0.02)$ & & 1.6 & \\
\hline & 1 & 1 & 1 & 0 & $18.80(0.02)$ & & & 0.30 \\
\hline & 1 & 1 & 1 & 1 & $23.50(0.02)$ & 4.70 & & 0.31 \\
\hline
\end{tabular}

${ }^{\mathrm{a}}$ 1,p, $\mathrm{q}$ and $\mathrm{r}$ are the stoichiometric coefficients corresponding to $\mathrm{Cu}^{\mathrm{II}}$, PVA, amino acids and $\mathrm{H}^{+}$respectively; the coefficient -1 refers to a proton loss

${ }^{\mathrm{b}} \log _{10} \beta$ of $\mathrm{Cu}-\mathrm{PVA}$-amino acids. Standard deviation are given in parentheses

${ }^{\mathrm{c}}$ The $\mathrm{pK}_{\mathrm{a}}$ of the ligands and the protonated species

${ }^{\mathrm{d}}$ Sum of squares of residuals 


\subsubsection{Complexes Involving DNA-Unit Constituents}

In the ternary complexes of DNA constituents, D, the potentiometric titration curves of the mixed ligand system (Fig. 4) could be fitted concerning the formation of the ternary complexes with stoichiometric coefficient 110, 111, 112 and 120. In this respect, The Cu"-PVA complex is first formed due to its greater stability compared to the Cu"-DNA complex (Table 2). Beyond $\mathrm{a}=2$, the formation of the ternary complex was ascertained by comparison of the mixed ligand titration curve with the binary complex Cu-PVA curve. The mixed ligand system was found to deviate considerably from the binary curve, indicating the formation of a ternary complex. Thus, the following equilibria can be written to describe the formation of the ternary complex (charges are omitted for simplicity) (Eqs. 3 and 4)

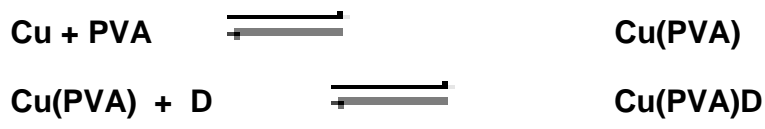

The pyrimidine species (uracil, uridine thymine and thymidine) have only basic nitrogen donor atoms ( $\mathrm{N}_{3}-\mathrm{C}_{4} \mathrm{O}$ group) in the measurable $\mathrm{pH}$ range and as a consequence they form 1:1 complexes with the $\mathrm{Cu}(\mathrm{PVA})$ ion. The thymidine complex is more stable than that with uridine, most probably owing to the higher basicity of the $\mathrm{N}_{3}$ of thymidine, resulting from the inductive effect of the extra electron-donating methyl group. As a result of the high $\mathrm{pKa}$ values of pyrimidine's $\left(\mathrm{pK}_{\mathrm{a}}>9\right)$ and the fact that they are monodentate, the complexes are formed only above $\mathrm{pH}=6$, supporting the view that the negatively charged nitrogen donors of pyrimidine bases are important binding sites in the neutral and slightly basic $\mathrm{pH}$ ranges. Mixed ligand complexes of nucleosides are less stable than the corresponding bases as is evident from the stability constants given in Table 2 . The presence of sugar residue imposes steric hindrance in nucleosides for their complexation with metal ions and reduces the overall basicity of metal complexes of nucleosides considerably. The purines inosine and inosine $5^{\prime}$-monophosphate (IMP) have two metal ion binding centers:

the $\mathrm{N}_{1}$ and $\mathrm{N}_{7}$ nitrogens. The $\mathrm{pH}$ dependent binding of these $\mathrm{N}$-donors was already reported. The results showed that inosine forms the complexes 110 and 111 , while inosine $5^{\prime}$-monophosphate forms 110, 111 and 112 complexes. Inosine- 5 -monophosphate (IMP) forms a more stable complex with $\mathrm{Cu}(\mathrm{PVA})$ than that with inosine. The extra stabilization can be attributed to the triply negatively charged $5^{\prime}$-IMP ${ }^{3-}$ ion. The speciation of inosine complexes is presented in Fig. 5, where the species distribution of the complexes is plotted as a function of $\mathrm{pH}$. The species 111 is formed in the acidic $\mathrm{pH}$ region and it corresponds to the $\mathrm{N}_{7}$ coordinated complex, while $\mathrm{N}_{1}$ nitrogen is in the protonated form. The $\mathrm{pK}$ a of the protonated form $\left(\log _{10} \beta_{111}-\log _{10} \beta_{110}\right)$ amounts to 7.93 . In the case of IMP, the protonated species formed correspond to a $\mathrm{N}_{7}$ coordinated complex, where the $\mathrm{N}_{1}$ nitrogen and the phosphate group are protonated. The $\mathrm{pK}$ a values of the protonated species of the IMP complex which corresponds to $\mathrm{N}_{1} \mathrm{H}$ group is $5.75\left(\log _{10} \beta_{112}-\log _{10} \beta_{111}\right)$. Whereas, the second

protonated species which corresponds to the $-\mathrm{PO}_{2}(\mathrm{OH})$, has a pKa value of $6.78\left(\log _{10} \beta_{11}-\log _{10} \beta_{110}\right)$. The $\mathrm{N}_{1} \mathrm{H}$ groups were acidified upon complex formation by 3.46 (9.21 to 5.75) pKa units. Acidification of the $\mathrm{N}_{1} \mathrm{H}$ group upon

complex formation is consistent with previous reports for IMP and AMP complexes [19]. The complexes formed with IMP are more stable than those of pyrimidines. The extra stabilization can be explained on the basis of different coulombic forces operating between the ions resulting from the negatively charged phosphate group. At higher $\mathrm{pH}$, the species 110 is formed with a maximum concentration of $60 \%$ at $\mathrm{pH} \approx 7.5$ for $\mathrm{Cu}$-PVA-inosine while in case of $\mathrm{Cu}$-PVA-thymidine, this species is $64 \%$ at $\mathrm{pH} \approx 6.5$. $(\mathrm{As}$ shown in Figs. 5 and 6).
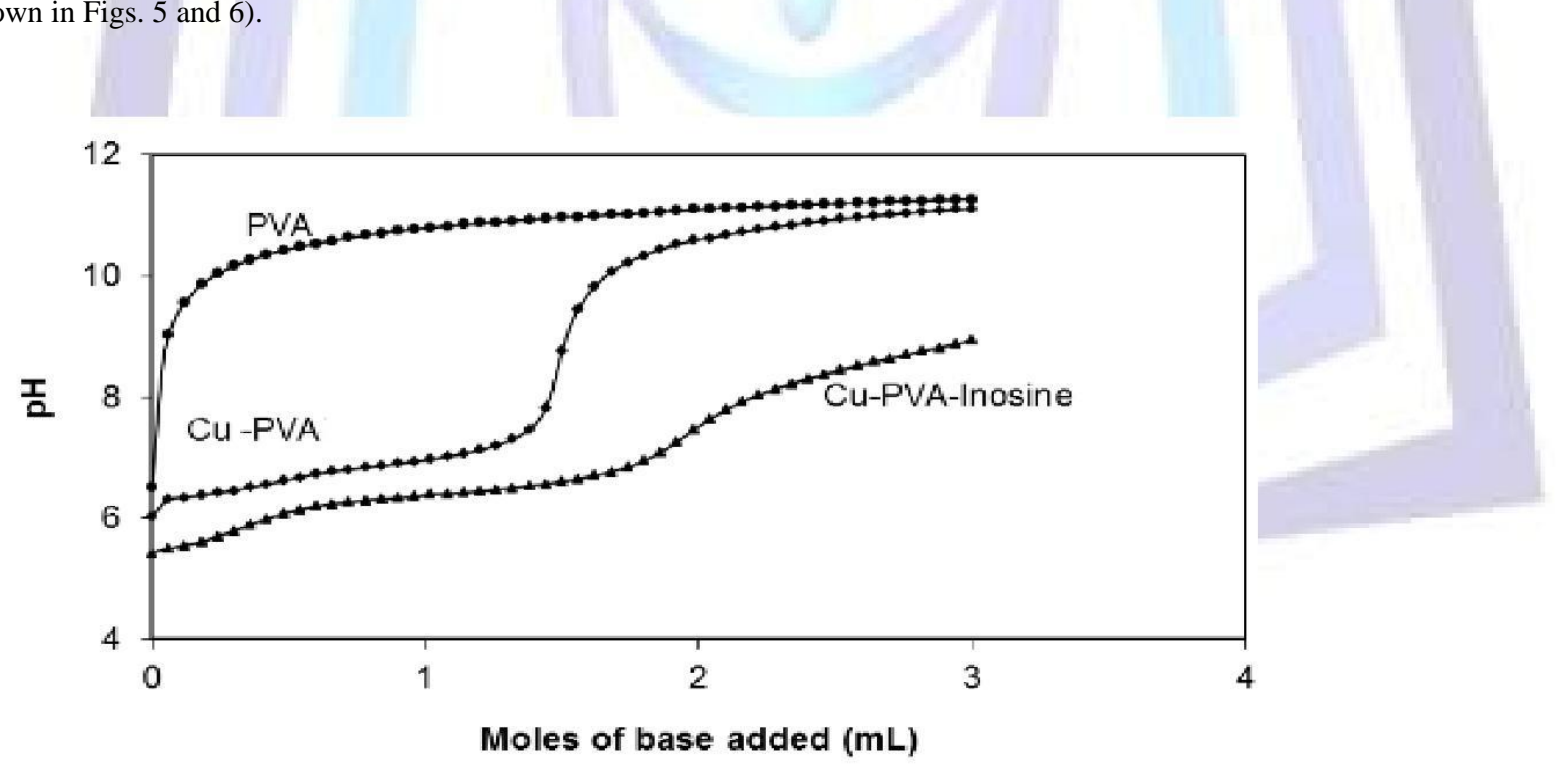

Fig 4: Potentiometric titration curve in the [Cu-PVA]-inosine system 


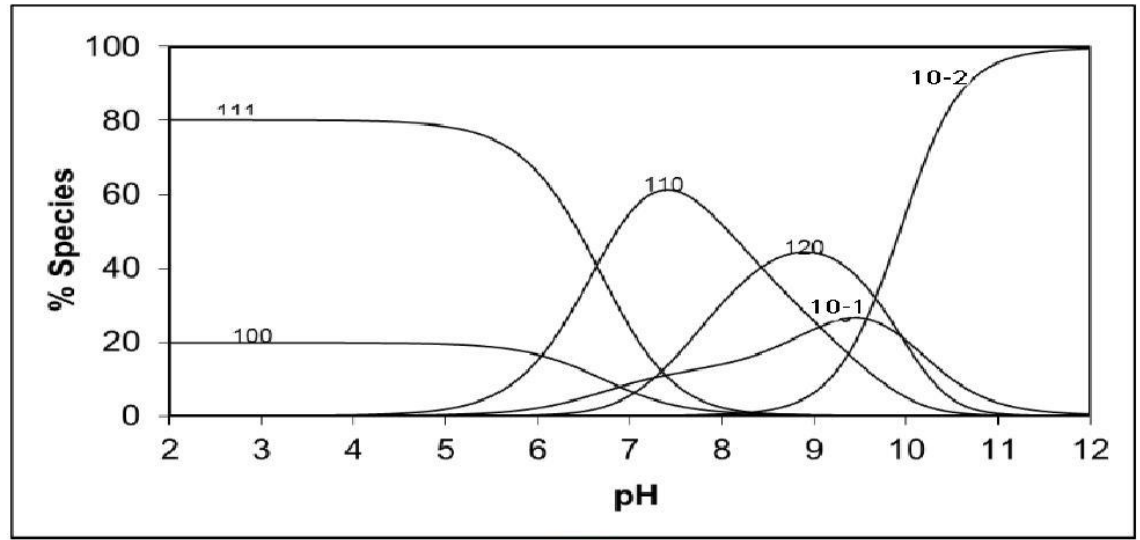

Fig 5: Concentration distribution of various species as a function of $\mathrm{pH}$ in the [Cu-PVA-inosine] system (each at a concentration of $1.25 \mathrm{mmol} \cdot \mathrm{L}^{-1}$ )

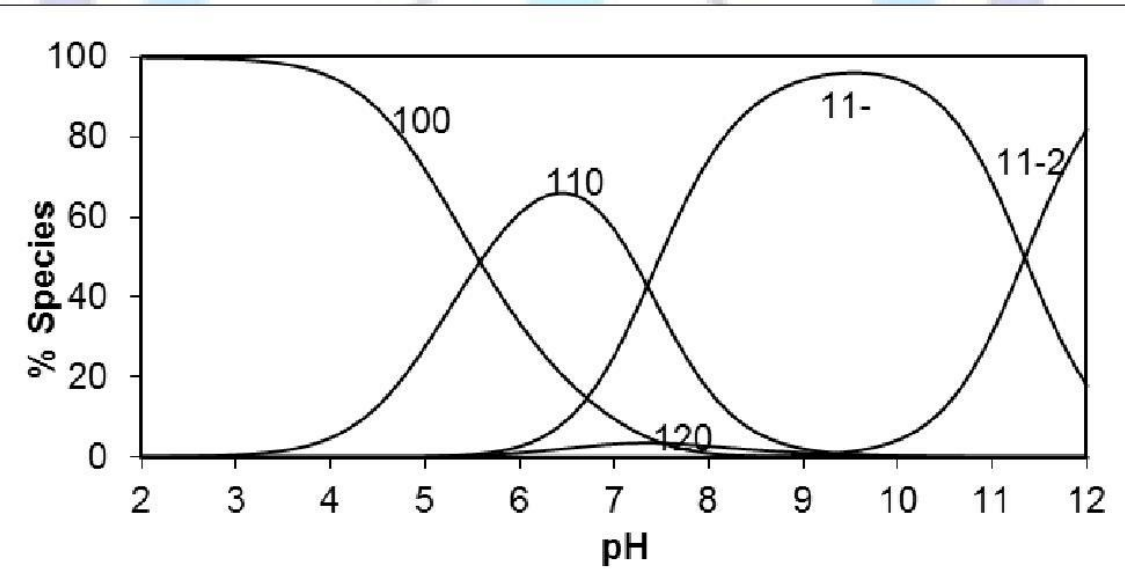

Fig 6: Concentration distribution of various species as a function of $\mathrm{pH}$ in the [Cu-PVA thymidine] system (each at a concentration of $1.25 \mathrm{mmol} \cdot \mathrm{L}^{-1}$ )

Table 2. Formation constants of Cu-PVA-DNA complexes at acids at $25^{\circ} \mathrm{C}$ and $0.1 \mathrm{M}$ ionic strength

\begin{tabular}{|c|c|c|c|c|c|c|c|c|}
\hline System & $\mathbf{p}$ & $\mathbf{q}$ & $r^{a}$ & $\begin{array}{c}b \\
\log _{10} \beta\end{array}$ & $\mathrm{pK}^{\mathrm{c}}$ & $\begin{array}{cc}\mathrm{d}^{-8} \\
\mathrm{~S} / \mathbf{1 0}\end{array}$ & $\log _{10} K^{C u D}$ & $\Delta \log _{10} K$ \\
\hline \multirow{3}{*}{ Uracil } & 0 & 1 & 1 & $9.28(0.06)$ & 9.28 & 2.4 & 5.49 & \\
\hline & 1 & 1 & 0 & $5.66(0.03)$ & & 1.5 & & 0.17 \\
\hline & 1 & 2 & 0 & $9.76(0.07)$ & & & & \\
\hline \multirow{3}{*}{ Uridine } & 0 & 1 & 1 & $9.01(0.04)$ & 9.01 & 8.7 & 4.03 & \\
\hline & 1 & 1 & 0 & $5.28(0.02)$ & & & & 1.25 \\
\hline & 1 & 2 & 0 & $9.16(0.09)$ & & & & \\
\hline \multirow{3}{*}{ Thymine } & 0 & 1 & 1 & $9.58(0.04)$ & 9.58 & 8.7 & 5.77 & \\
\hline & 1 & 1 & 0 & $6.50(0.06)$ & & & & 0.73 \\
\hline & 1 & 2 & 0 & $10.75(0.09)$ & & & & \\
\hline \multirow{3}{*}{ Thymidine } & 0 & 1 & 1 & $9.50(0.01)$ & 9.50 & 20 & 4.71 & \\
\hline & 1 & 1 & 0 & $6.35(0.04)$ & & & & \\
\hline & 1 & 2 & 0 & $10.53(0.08)$ & & & & \\
\hline
\end{tabular}




\begin{tabular}{|c|c|c|c|c|c|c|c|c|}
\hline \multirow{4}{*}{ Inosine } & 0 & 1 & 1 & $8.43(0.04)$ & 8.43 & 1.4 & 4.50 & \\
\hline & 1 & 1 & 0 & $4.87(0.04)$ & & & & 0.37 \\
\hline & 1 & 1 & 1 & $12.80(0.02)$ & 7.93 & 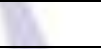 & & + \\
\hline & 1 & 2 & 0 & $8.41(0.06)$ & & 5.7 & & \\
\hline \multirow{5}{*}{$\begin{array}{l}\text { Inosine-5 - } \\
\text { monophosphate }\end{array}$} & 0 & 1 & 1 & $9.21(0.04)$ & 9.21 & 6.11 & 3.50 & \\
\hline & 1 & 1 & 0 & $6.95(0.04)$ & & 120 & & 3.40 \\
\hline & 1 & 1 & 1 & $13.73(0.07)$ & 6.78 & & & \\
\hline & 1 & 1 & 2 & 19.48(0.08) & 5.75 & & & \\
\hline & 1 & 1 & 1 & $12.80(0.02)$ & 7.93 & & 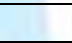 & \\
\hline \multirow{5}{*}{$\begin{array}{l}\text { Adenosine-5 - } \\
\text { monophosphate }\end{array}$} & 0 & 1 & 1 & $7.17(0.05)$ & 7.17 & 11 & 3.03 & \\
\hline & 0 & 1 & 2 & $10.28(0.06)$ & 3.11 & & & \\
\hline & 1 & 1 & 0 & $4.71(0.06)$ & & 20 & & 1.68 \\
\hline & 1 & 1 & 1 & $11.08(0.05)$ & 6.37 & & & \\
\hline & 1 & 1 & 2 & $16.88(0.07)$ & 5.80 & & & \\
\hline
\end{tabular}

${ }^{\mathrm{a}} \mathrm{p}, \mathrm{q}$ and $\mathrm{r}$ are the stoichiometric coefficients corresponding to [Cu-PVA], DNA units and $\mathrm{H}^{+}$, respectively

${ }^{b} \log _{10} \beta$ of [Cu-PVA]-DNA units. ${ }^{C}$ Standard deviation are given in parentheses

The $\mathrm{pK}_{\mathrm{a}}$ of the protonated species $\left(\log _{10} \beta_{111}-\log _{10} \beta_{110}\right)$

${ }^{\mathrm{d}}$ Sum of squares of residuals

\subsection{Comparison of the Stability Constant of the Ternary Complexes with those of the Binary Complexes}

Although the constant $\beta_{1110}$ expresses the overall stability of the ternary complex [Cu(PVA)L] as expressed by Eq. 1, it does not represent directly the binding strength between the amino acids and the copper(II) ion. The tendency towards ternary complex formation can be evaluated in various ways. $\Delta \log _{10} \mathrm{~K}$ has been widely accepted and used for many years [20] and the advantages of using $\Delta \log _{10} \mathrm{~K}$ in comparing stabilities of ternary and binary complexes have been reviewed. The $\Delta \log _{10} \mathrm{~K}$ value for protonated deprotonated amide complex can be calculated using Eq. 8

$\Delta \log _{10} K=\log _{10} \beta_{1111}-\log _{10} \beta_{1100}-\log _{10} \beta_{1011}$
$\Delta \log _{10} K=\log _{10} \beta_{1110}-\log _{10} \beta_{1100}-\log _{10} \beta_{1010}$
$\Delta \log _{10} K=\log _{10} \beta_{111-1}-\log _{10} \beta_{1100}-\log _{10} \beta_{101-1}$

The values of $\Delta \log _{10} \mathrm{~K}$ for the ternary complexes studied in this paper are listed in Table 1 . The theoretical $\Delta \log _{10} \mathrm{~K}$ value, for a square planar copper(II) complex is -0.9 [20]. The tendency to form ternary complexes was compared with this value, so that if $\Delta \log _{10}$ $\mathrm{K}$ is greater than -0.9 , this should be taken to indicate that the ternary complex is favored. The calculated $\Delta \log _{10} \mathrm{~K}$ values of $\alpha$-amino acids are less negative than the theoretical value (-0.90). This may be considered as evidence for the occurrence of enhanced stabilities involving $\pi$-back-donation from the negatively charged amino acid to the $\mathrm{Cu}(\mathrm{PVA})$ system. The $\Delta \log _{10} \mathrm{~K}$ values for the ternary complexes of $\beta$-phenylalanine are much less negative than -0.9 , or positive. This may be explained on the premise that the presence of an aromatic ring above the $\mathrm{Cu}(\mathrm{II})$ coordination plane is probably essential for preferential formation of ternary complexes. The relative stability of the ternary complexes formed through a stepwise mechanism, as compared to those of the corresponding binary complex, is expressed in terms of $\Delta \log _{10} \mathrm{~K}$ as defined by Eq. 9

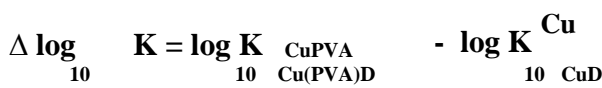

The $\Delta \log _{10} \mathrm{~K}$ values, Table 2 , are invariably positive. This means that the DNA constituents form more stable complexes with $\mathrm{Cu}$ (PVA) than with the free copper(II) ion. Before discussing the results of spectrophotometric measurements, it should be pointed out that the spectrum of aquated copper(II) ion (mixture 1) consists of a broad, weak band $(\varepsilon=62)$ with a maximum wave length at 807 $\mathrm{nm}$, attributed to the $2 \mathrm{~T}_{2} \mathrm{~g} \leftarrow 2 \mathrm{Eg}$ transition [21, 22]. The spectral bands of the binary and ternary copper(II) complexes, shown in Figures 7 and 8 are quite different from that of the aquated copper(II) ion, both as regards the position of the maximum wavelength and their average molar absorptivity. The spectrum of the $\mathrm{Cu}$ (PVA) complex (curve 4) shows an absorption maximum at $750 \mathrm{~nm}(\varepsilon=259)$. On the other hand the spectra obtained from the ternary complex of copper(II) with PVA and glycine or thymidine a appearing at 730 $\mathrm{nm}(\varepsilon=537)$ and $735 \mathrm{~nm}(\varepsilon=530)$ respectively. This shift in the absorption spectrum towards shorter wavelength (blue shift) is an evidence of the binary and ternary complexes formation together with the potentiometric measurements. 

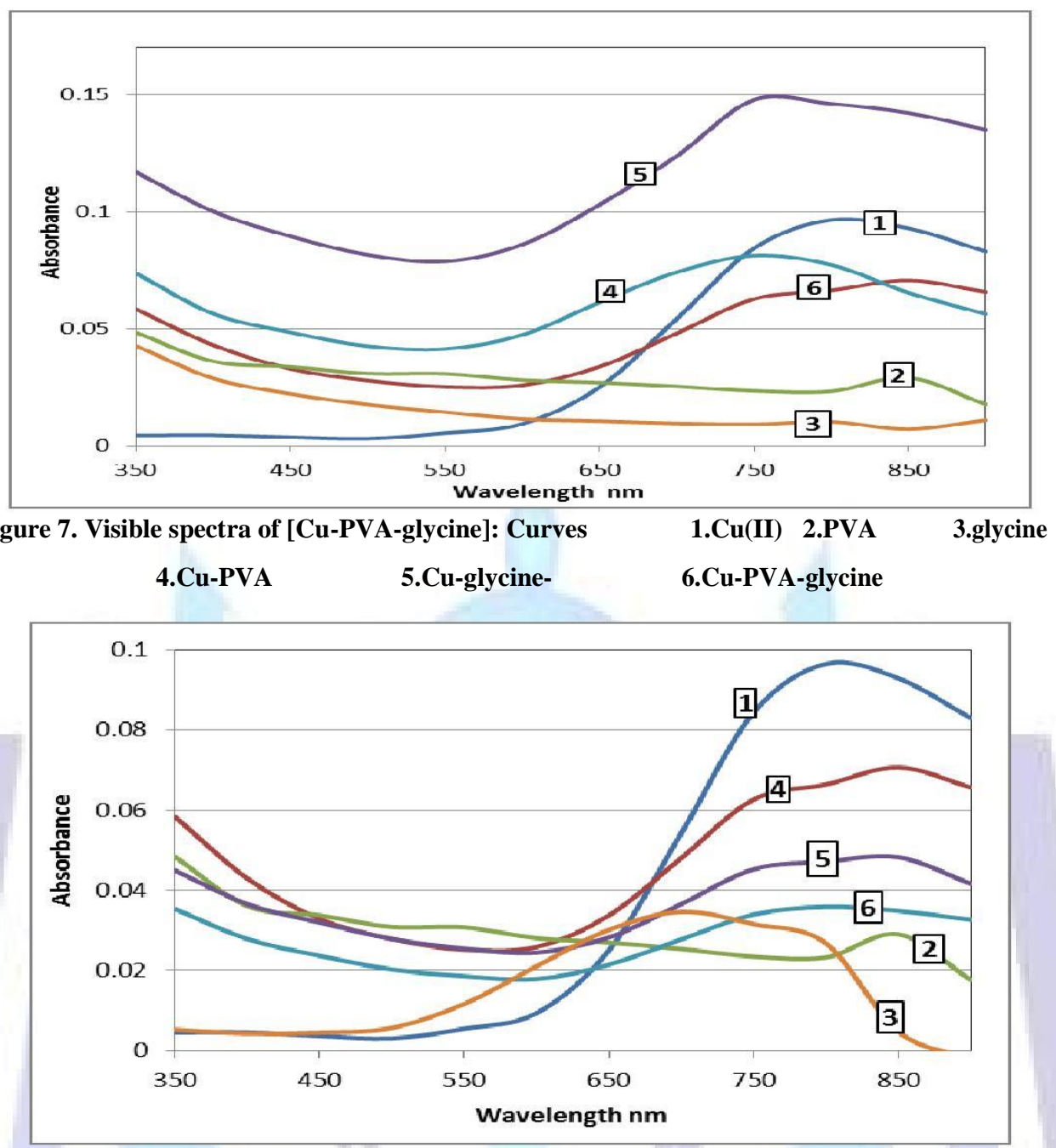

Figure 8. Visible spectra of [Cu-PVA-thymidine]: Curves

\section{Cu-PVA}

\section{Cu- thymidine}

\subsection{Antimicrobial Activity}

One of the recent studies on the copper chelates are well known to have an enhanced antimicrobial activity; therefore it seems interesting to screen the biological potential of the complexes, in vivo, against different species of bacteria and fungi. In testing the antimicrobial activity of these compounds, we used more than one test organism to increase the chance of detecting antibiotic principles in tested materials. All of the tested compounds show a remarkable biological activity against Gram-positive (G+) and Gram-negative $\left(\mathrm{G}^{-}\right)$bacteria and also fungi. The data are listed in Table 3. The biological activity of the metal complexes is governed by the following factors [23]: (i) the chelate effect of the ligands, (ii) the nature of the donor atoms, (iii) the total charge on the complex ion, (iv) the nature of the metal ion, (v) the nature of the counter ions that neutralize the complex, and (vi) the geometrical structure of the complex [24]. Furthermore, the increase in biological activity of the metal chelates may be due to the effect of the metal ion on the normal cell process. A possible mode of toxicity may be considered in the light of Tweedy's chelation theory [25]. Chelation considerably reduces the polarity of the metal ion because of partial sharing of its positive charge with the donor group and possible $\pi$-electron delocalization within the whole chelate ring system that is formed during coordination. Such chelation could enhance the lipophilic character of the central metal atom and hence increase the hydrophobic character and liposolubility of the complex favoring its permeation through the lipid layers of the cell membrane. This enhances the rate of uptake/entrance and thus the antimicrobial activity of the tested compounds. Accordingly, the antimicrobial activity of the complexes present in this investigation can be referred to the increase of their lipophilic character, which in turn deactivates enzymes responsible for respiration processes and probably other cellular enzymes, which play vital roles in various metabolic pathways of the tested micro-organisms. On comparing the biological activity. The results of the antibacterial and antifungal activity of the Cu-PVA-glycine and Cu-PVA-thymidine as representative complexes are recorded in Table 3. The activity of the complexes has been compared with the activity of a common standard tetracycline (antibacterial agent) and amphotricine B (antifungal agent), the following results are obtained: 
(a) Using Escherichia coli (G-) and Staphylococcus aureus $\left(\mathrm{G}_{+}\right)$: the biological activity of the PVA- Cu-Glycine complex is higher than that of the PVA-Cu-thrymidine complex and slightly lower than that of the tetracycline standard.

(b) Using Aspergillus flavus fungus: the antifungal activity of the Cu-PVA and the glycine are higher than that of the Cu-PVAthymidine but lower than that standard antifungal agent Amphotericin B

(c) Using Candida albicans fungus: The biological activities of the Cu-PVA with glycine or thymidine complexes are found to have lower values than that of the standard Candida albicans.

The tested complexes were more active against Gram +ve than Gram -ve bacteria; it may be concluded that the antibacterial activity of the compounds is related to cell wall structure of the bacteria. The differences in cell wall structure can produce differences in antibacterial susceptibility and some antibiotics can kill only Gram +ve bacteria and are ineffective against Gram -ve pathogens [26]. The cell wall is essential to the survival of bacteria and some antibiotics are able to kill bacteria by inhibiting the synthesis of peptidoglycan (a component of bacterial cell wall). Gram +ve bacteria possess a cell wall containing a thick layer of peptidoglycan and teichoic acid, while Gram -ve bacteria have a relatively thin cell wall consisting of one layer of peptidogly can surrounded by a second lipid membrane containing lipopolysaccharides and lipoproteins. These may explain why the complexes have a high antibacterial activity against Gram +ve bacteria than Gram -ve bacteria.

Table 3. The antibacterial and antifungal activity of the synthesized metal complexes

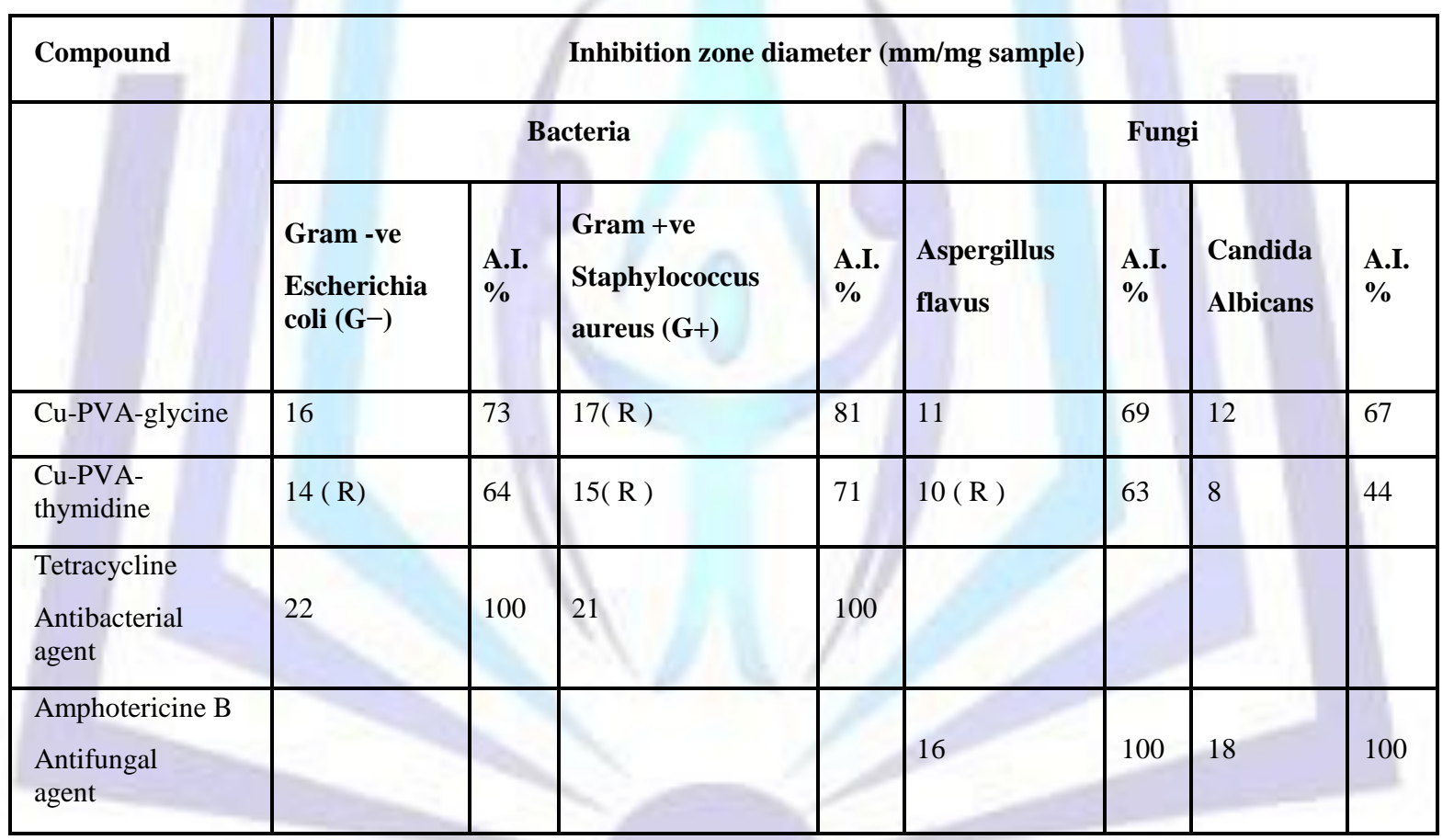

R: Repellent (not complete inhibition)

\section{A.I.: Activity Index}

\section{Conclusions}

The present investigation may have important biological implications. The formation equilibria of $\mathrm{Cu}(\mathrm{II})$ complexes involving PVA and some ligands of biological significance were investigated. In combination with stability constants data of such [Cu(PVA)] complexes with amino acids and DNA constituents, it will be possible to calculate the equilibrium distribution of the metal species in biological fluids where all types of ligands are present simultaneously. This would form a clear basis for understanding the mode of action of such metal species under physiological conditions. The amino acids complexes are more stable than those of the DNA constituents. The $\beta$-alcoholate group in the side chain of the amino acid threonine have been found to play an essential role in the function of a number of proteolytic enzymes, for example chymotrypsin and subtilisin. $\mathrm{Cu}(\mathrm{PVA})$ promotes the ionization of the alcohol group of threonine with $\mathrm{pKa}$ value of 7.68. This indicates that the participation of the $\mathrm{OH}$ group in complex formation is not contributing significantly in the physiological $\mathrm{pH}$ range. The results of antimicrobial activity show that the complexes exhibit antimicrobial properties. Also, the results indicated that the tested complexes were more active against Gram-negative than Grampositive bacteria. The importance of this lies in the fact that such compounds may have a possible antitumor effect since Gramnegative bacteria are considered a quantitative microbiological method for testing beneficial and important drugs in both clinical and experimental tumor chemotherapy [27]. 


\section{References}

[1] Prichard, G.J., (1970) Poly(vinyl alcohol): Basis principles and uses. Gordon and Breach, New York.

[2] Brunelli, D.D., Barboza, V.C., Joekes, Atvars TDZ (1998) Mapping phases of poly(vinyl alcohol) and poly(vinyl acetate) blends by Ft-Ir microspectroscopy and optical fluorescence microscopy. Journal of Applied Polymer Science, 69: 645-655.

[3] Garrel, D.R., Gaudreau, P., Zhanf, L.M., Reeves, I., Brazeau, P. (1991) Chronic administration of growth hor- monereleasing factor increases wound strength and col-lagen maturation in granulation tissue. The Journal of surgical research, 51: 297-302.

[4] Kim, J.H., Kim, J.Y., Lee, Y.M., Kim, K.Y. (1992) Properties and swelling characteristics of cross- linked poly(vinyl alcohol)/chitosan blend membrane. Journal of Applied Polymer Science, 45: 1711-1717.

[5] Saxena, A.K., Marler, J., Benvenuto, M., Willital, G.H., Vacanti, J.P. (1999) Skeletal muscle tissue engineering using isolated myoblasts on synthetic biodegradable polymers: Preliminary studies. Tissue Engineering, 5: 525-532.

[6] Peppas, N.P., Merril, E.W. (1977) Development of semicrystalline poly(vinyl alcohol) hydrogels for bio-medical application. Journal of Biomedical Materials Re- search, 11: 423-434.

[7] Welcher, F.J. (1965) The Analytical Uses of Ethylenediamine Tetraacetic Acid. Van Nostand, Princeton.

[8] Grayer, R.J., Harbone, J.B. (1994) A survey of antifungal compounds from higher plants, 1982-1993. Photochemistry, 7: $19-42$.

[9] Mohamed, G.G., Soliman, M.H. (2010) Synthesis, spectroscopic and thermal characterization of sulpiride complexes of iron, manganese, copper, cobalt, nickel, and zinc salts. Antibacterial and antifungal activity Spectochim Acta A: 341-347.

[10] Vogel, A.E. (1989) Text Book of Quantitative Chemical Analysis, 5th ed., p. 555. Longman, Harlow, Chap. 15.

[11] Stark, J.G., Wallace, H.G. (1975), (eds.): Chemistry Data Book, p. 75. Murray, London.

[12] Gans, P., Sabatini, A., Vacca, A. (1976) An improved computer program for the computation of formation constants from potentiometric data J Inorg. Chim. Acta 18: 237-239.

[13] Pettit, L. (1993) Personal Communication. University of Leeds.

[14] Shehata, M.R., Shoukry, M.M., Nasr, F.M., Van Eldik, R. (2008) Complex-formation reactions of dicholoro(S-methyl-Lcysteine)palladium(II) with bio-relevant ligands. Labilization induced by S-donor chelates Dalton Trans. 779-786

[15] Shoukry, A.A., Hosny, W.M. (2012) Coordination properties of N,O- arboxymethylchitosan (NOCC). Synthesis and equilibrium studies of some metal ion complexes. Ternary complexes involving $\mathrm{Cu}(\mathrm{II})$ with (NOCC) and some biorelevant ligand. Cent. Eur. J Chem. Eur.(10)(1): 59-70.

[16] Hosny, W.M., Khalaf-Alaa, P.A. (2013) Potentiometric Study and Biological Activity of some Metal Ion Complexes of Polyvinyl Alcohol (PVA). Int. J Electrochem. Sci., 8: 1520-1533.

[17] Sigel, H., Martin, R.B. (1982) Coordination properties of the amide bond stability and structure of metal ion complexes of peptides and related ligands. Chem. Rev. 82: 385-426.

[18] Grenouillet, P., Martin, R.P., Rossi, A., Ptak, M. (1973) Interactions between copper(II) ions L- threoinine,L-allothreonine and L-serine in aqueous solutions. Biochim. Biophys Acta 322: 185- 194.

[19] Sigel, H., Massoud, S.S., Corfu, N.A. (1994) Comparison of the extent of base back binding in complexes of divalent metal ions with guanine $\left(\mathrm{GMP}^{2-}\right)$, inosine $\left(\mathrm{IMP}^{2-}\right)$ and adenosine 5-monophosphate $\left(\mathrm{AMP}^{2-}\right)$. The crucial role of N-7 basicity in metal ion- nucleic base recognition. J Am Chem. Soc. 116: 2958-2971.

[20] Sigel, H. (1975) Ternary $\mathrm{Cu}^{2+}$ complexes stability, structure, and reactivity. Angew Chem. Int. Ed.14: $394-402$.

[21] Cotton, F.A., Wilkinson, G. (1973) Basic Inorganic Chemistry, pp.: 353-379. Wiley, New York . Part 3. 
[22] Shoukry, M.M., Saeed, A., Khairy, E.M. (1989) Equilibrium and hydrolysis of $\alpha$-amino acid esters in ternary complexes of copper(II) involving glycol-L-tyrosine. Transit Metal Chem. 14: 347-350.

[23] Chohan, Z.H. (2005) Antibacterial and antifungal ferrocene incorporated dithiothione and dithioketone compounds Appl Organomet. Chem. 20: 112-116.

[24] Russell, A.D. (1991) Densification, Sterilization and Preservation, 4th ed. Lee and Febinger, Philadelphia.

[25] Tweedy, B.G. (1964) Possible mechanism for reduction of elemental sulfur by Monilinia fructicola. Phytopathology 55: 910914.

[26] Koch, A.L. (2003) Bacterial wall as target for attack: past, present, and future research. Clin. Microbiol. Rev. 16: 673.

[27] Inoue, T., Yamashita, Y., Nishihara, M., Sugiyama, S., Sonoda, Y., Kumabe, T., Yokoyama, M., Tominaga,T. (2009) Therapeutic efficacy of a polymeric micellar doxorubicin infused by convection- enhanced delivery against intracranial $9 \mathrm{~L}$ brain tumor models. Neuro-oncology 11: 151-157. 